\title{
Geotechnical aspects of Alluvial soils at different depths under sodium chloride action, Najran region, Saudi Arabia: Field supported by laboratory tests
}

Ahmed Abd El Aal ( $\sim$ ahmed_aka80@yahoo.com )

Najran University Faculty of Engineering https://orcid.org/0000-0001-9077-6897

Gamil Abdullah

Najran University Faculty of Engineering

\section{Research Article}

Keywords: Salts, Semi-arid Soils, Stabilization, geotechnical aspects; Najran; Saudi Arabia.

Posted Date: June 25th, 2021

DOl: https://doi.org/10.21203/rs.3.rs-441231/v1

License: (c) (1) This work is licensed under a Creative Commons Attribution 4.0 International License.

Read Full License 


\section{Abstract}

The present work is to investigated the effect of sodium chloride $(\mathrm{NaCl})$ on the behavior of semi-arid soils in the Najran region of Saudi Arabia. An experiment work was carried out to investigate how the addition of ( $\mathrm{NaCl})$ "salt" to semi-arid soils collected from Najran region affects the Atterberg limits, compaction characteristics, California Bearing Ratio (CBR) and shear strength. All tests were performed on soils samples collected from different areas in Najran region at various depths of 1.5, 3, and $4.5 \mathrm{~m}$ along soil profiles. Soils samples were tested alone and then compared with the same soils samples mixed with sodium chloride (salt) at different percentages of 5,10 , and $20 \%$ respectively. Using advanced techniques, such as the scanning electron microscope (SEM), energy dispersive x-ray analysis (EDX) and X-ray diffraction analysis (XRD), the process of stabilization was examined. The results showed that salt has a major impact on the geotechnical characteristics of semi-arid soils. With the addition of sodium chloride, the maximum dry density increased and the optimal water content decreased with the increase in the added salt percentage. The liquid and plastic limits and, in turn, plasticity index reduced as the added percentage of sodium chloride increased. Furthermore, significant increase in CBR and shear strength parameters was noticed. It is therefore concluded that, the sodium chloride could be a good stabilizing agent, particularly at $20 \%$ and could be used as a sub-base material in road construction. Technical and economic advantages arise from the implementation of $\mathrm{NaCl}$.

\section{1- Introduction}

In all continents and under almost all climatic conditions, salt-affected soils are present. In the arid and semi-arid areas, however, their range is comparatively more widespread compared to the tropical regions. The main point from an engineering perspective is to enhance the mechanical characteristics of the soil in terms of strength, durability and also in terms of the cost, to be used as building materials. Mechanochemical substances may be used to stabilize poor soils, incorporating agents that assist in improving the mechanical characteristics of stabilized soils. Stabilizers to be used must fulfil visible behavior, reliability, lower cost and can be quickly applied (Al Homdiy et al., 2017). Najran area is an important region in Saudi Arabia and civilization is currently increasing rapidly due to the flourishing diversity of economic resources (Najran granite, industrial aggregates) and a significant position on the Kingdom of Saudi Arabia's southern border. Over the last three decades, the area of the town has increased to cover much of the low-lying areas surrounding the old city of Najran. The foundation bed is typically made of clay and sandy silt. In order to obviate future threats in the building of the new urban governorate around Najran city, which was built on clayey soil, evaluation of geotechnical aspects of this bed was necessary (Abd El Aal, Rouaiguia, 2020). The form and depth of foundations required will be influenced by the hazards associated with the different ground conditions described (El-Shafie, 2010). Soils usually contain little to no salt in humid areas, and soil water is comparatively poor in dissolved salt-related ions. This is because abundant rainfall leaches any salt present in the soil and transfers saltrelated ions downwards past the root zone (and in some places, abundant snowmelt). There is a 
relatively higher level of chemical reactions and weathering of earth materials, such as soils, minerals and rocks, resulting in the accumulation of different natural salts.

The speed at which moisture is found in the atmosphere via soil evaporation and plant-process transpiration, collectively called evapo-transpiration, is relatively high. For arid and semi-arid areas, the rate of chemical weathering is greater than for humid areas because air and soil temperatures are higher. In arid and semi-arid areas, evapo-transpiration rates surpass those of humid regions because the solar radiation in the former is higher and the air is drier there. Traffic is quickly compacted by snow-fall on roads to create a hard crust. Sodium chloride (salt) is also added to the road in a measure called anticompaction, to prevent crust formation. In the planet, many arid areas are close to oceans, rivers, or freshwater saline lakes. Earlier, numerous studies on enhancing the characteristics of susceptible soils have been carried out using some additives such as $\mathrm{Ca}_{2} \mathrm{CO}_{3}$, gypsum, cement and cement kiln mud, such as works by López and Castaňo (2001),Muntohar and Hantoro (2000) and Miller and Azad (2000).

The effects of popular salts on the index, physical and mechanical properties of soils rather than semiarid soils such as black cotton soils have been investigated by several researchers (Dubey and Jain, 2015; Guttikonda and Abhilash, 2018), expansive soils (Durotoye et al. 2016), clay soils (Peddaiah and Suresh, 2017; Afrin, 2017), silty clay soils (Abood et al. 2007). Both previous studies have shown that the addition of different salt additive percentages led to the increase in the maximum dry density and decrease in the optimum water content. In addition, as the content of salts increased, the Atterberg's limits and plasticity index decreased.

Abdullah and Al-Abdul Wahhab (2015), (2018) have investigated stabilization of marginal soils (dune sand, sabkha and marl) covering most areas of Saudi Arabia's eastern and western parts. Using various stabilizers (sulfur foamed and emulsified sulfur asphalt), they studied the treatment of these soils and concluded that the stabilized soils could be used as the base layer in road construction.

Al-Malak et. al (2016); Al-Amoudi et. al (2017), Al-homidy et. al (2017) Rouaiguia and Abd El Aal, (2020) have also used several other stabilizers, such as cement kiln dust CKD, ash flay oil, lime and marble powder.

This study focus on investigation the effects of salts, namely, $\mathrm{NaCl}$ on the index and engineering aspects of soils in arid environment at Najran area, which are semi-arid soils and have not been investigated before.

\section{Procedures And Methods}

\subsection{Material Collection and Characterization}

\subsubsection{Soils}


Soil samples were collected from Najran region, Kingdom of Saudi Arabia (Fig. 1a) for a project proposal for completion Najran interchange, Najran airport (Bridge No. 2). Road holes are ideal ways to analyze the layers within a soil profile, or horizons. Figure 2 below shows a road cut that demonstrates the number of layers that may exist in the soil of the Najran area. Soil samples were transported to the laboratory after processing, and a sieve analysis in accordance with AASHTO T87 (ASTM D 421) was conducted.

This analysis was established on the soil section demonstrated in (Fig. 1b and c), presumed that the details provided by most soil profiles was almost identical. At a depth of $12 \mathrm{~m}$, the borehole ended. A standard profile (borehole log) of Najran soil is shown in Fig. 1d. It is noted that the moisture content and the number of blows $(\mathrm{N})$ of SPT increased with depth, and at the time of the examination, the groundwater table was not found over the entire $12 \mathrm{~m}$ depth. The moisture content and the saturation degree at the site ranged from 2.2 percent to 5 percent and from 7.20 percent to 18.35 percent for a depth ranging from 0 to $4.5 \mathrm{~m}$, respectively. It should be remembered that even with soil depth, the degree of saturated soil rises.

\subsubsection{The Sodium Chloride "NaCl"}

$\mathrm{NaCl}$ has properties comparable to those of $\mathrm{CaCl}$. A significant improve in California Bearing Ratio (CBR), unconfined compressive strength (UCS), and indirect tensile strength of salt stabilized material have been documented by Singh and Das (1999). Long-term road subgrade is the primary application of sodium chloride (Singh and Das, 1999).

\subsubsection{Mineralogical analysis}

X-ray diffraction (XRD) technique using diffractometer Philips PW 1840 was used to analyze ten powder samples prepared from the collected blocks. Patterns were run with $\mathrm{Ni}$-filtered $\mathrm{Cu}$ Ka radiation $(\mathrm{k}=$ $1.54056 \mathrm{~A}^{\circ}$ ) at $40 \mathrm{kv}$ and $10 \mathrm{~mA}$, with scanning limited from $2 \theta=10$ to $80 \mathrm{o}$. The scanning electron microscope (SEM) supported with energy dispersive analytical x-ray (EDAX) was used in the same way described by Abd El-Aal et al. (2020), to characterize the microstructural characteristics and the elemental composition of the studied tufas.

\subsubsection{Atterberg Limits Tests}

Via Sieve Number 40, the soil samples were sieved. Sodium chloride was applied to each tested soil in increments of 5,10 , and 20 percent by weight. Every soil was then carefully mixed with distilled water and left to heal and obtain a homogeneous paste for two hours. For each increment, the liquid and plastic limit tests were conducted using the dropping cone method and B.S. 1377- Research procedures from 1990.3.

\subsubsection{Standard Proctor Test}

Standard Proctor test was conducted in accordance with AASHTO T99 (ASTM D 698) on each soil samples passing No. 4 sieve, compacting the soil with a $5.5 \mathrm{lb}$ hammer dropping into a soil filled mold at a distance of one foot to produce compaction energy of $12,400 \mathrm{ft}-\mathrm{lbf} / \mathrm{ft}^{3}$. Soils samples are compacted 
as three layers in the mold and 25 drops of the hammer are applied to each layer. Water was added for each soil sample to get it to a predetermined percentage of moisture content.

\subsubsection{California Bearing Ratio (CBR) Test}

California bearing ratio is considered an important test for the performance evaluation of the materials proposed to be used in pavement structure layers. The test could be done either dry or soaked. The soaked test is more realistic and simulates the real field conditions in its worst case (i.e. flood). Therefore, soaked CBR test was performed in soils specimens prepared with the optimum moisture content and at a range of dry density by changing the compaction energy applied to each layer in the compaction CBR mold. This was done to come up with the curves of various dry densities versus their corresponding CBR ratios. The soaked CBR test was performed in compliance with AASHTO T 193 and (ASTM D698-70) specifications.

\subsubsection{Shear Strength Test}

It is well known that soils fail under shearing when subjected to a heavy loading. Thus, to assess the shear strength of stabilized soils, direct shear box test was conducted on the natural semi-arid soils specimens as well as on the treated soils samples salt $(\mathrm{NaCL})$ collected from different depths $(1.5,3$ and $4.5 \mathrm{~m}$ ). The test was conducted according to ASTM D3080-98 specification on the treated soil mix that gave higher maximum dry density in the compaction test.

\section{Results}

\subsection{Soils Gradation and Characterization}

The grain size distributions curves for the soils are plotted in Fig. 2. The distribution of particle size is normally composed of 87.3 percent sand, 10.1 percent silt, and 2.6 percent of clay fraction at $1.5 \mathrm{~m}$ depth, 86.6 percent sand, 10.6 percent silt, and 2.8 percent of clay fraction at $3 \mathrm{~m}$ depth, and 86 percent sand, 10.3 percent silt, and 3.7 percent of clay fraction at $4.5 \mathrm{~m}$ depth. The tested soil is known as silty sands (SM) by the use of the Unified Soil Classification System (USCS).

The average values of physical characteristics of the soil at depth $1.5,3$, and $4.5 \mathrm{~m}$. The highest value of Moisture content, Specific gravity Bulk density, Dry density, Void Ratio, Porosity and Degree of saturation are $5 \%, 2.68 \mathrm{~g} / \mathrm{cm} 31.74 \mathrm{~g} / \mathrm{cm} 3,1.66 \mathrm{~g} / \mathrm{cm} 3,0.73 \%, 0.41 \%$ and $18.35 \%$ respectively, are listed in Table 1 , whereas Table 2 presents their description and classification according to USCS and AASHTO specifications. 
Table 1

The physical characteristics used in the investigation of Najran soils.

\begin{tabular}{|llllllll|}
\hline $\begin{array}{l}\text { Depth } \\
(\mathrm{m})\end{array}$ & $\begin{array}{l}\text { Moisture } \\
\text { content } \\
(\%)\end{array}$ & $\begin{array}{l}\text { Specific } \\
\text { gravity }\end{array}$ & $\begin{array}{l}\text { Bulk density } \\
\left(\mathbf{g} / \mathrm{cm}^{3}\right)\end{array}$ & $\begin{array}{l}\text { Dry density } \\
\left(\mathbf{g} / \mathrm{cm}^{3}\right)\end{array}$ & $\begin{array}{l}\text { Void } \\
\text { Ratio } \\
\%\end{array}$ & $\begin{array}{l}\text { Porosity } \\
\%\end{array}$ & $\begin{array}{l}\text { Degree of } \\
\text { saturation } \\
(\%)\end{array}$ \\
\hline $\mathbf{1 . 5}$ & 2.2 & 2.65 & 1.58 & 1.54 & 0.81 & 0.44 & 7.20 \\
\hline $\mathbf{3}$ & 3.5 & 2.71 & 1.67 & 1.61 & 0.76 & 0.43 & 12.48 \\
\hline $\mathbf{4 . 5}$ & 5.0 & 2.68 & 1.74 & 1.66 & 0.73 & 0.41 & 18.35 \\
\hline
\end{tabular}

Table 2

Mechanical analysis of Najran soils.

\begin{tabular}{|lllllll|}
\hline $\begin{array}{l}\text { Depth } \\
(\mathbf{m})\end{array}$ & $\begin{array}{l}\text { Sand } \\
(\mathbf{\%})\end{array}$ & $\begin{array}{l}\text { Silt } \\
(\mathbf{\%})\end{array}$ & $\begin{array}{l}\text { Clay } \\
(\mathbf{\%})\end{array}$ & Description of Soil & USCS & AASHTO \\
\hline $\mathbf{1 . 5}$ & 87.3 & 10.1 & 2.6 & Pale brown, silty sand & SM & A-2-4 (0), A-5 \\
\hline $\mathbf{3}$ & 86.6 & 10.6 & 2.8 & Pale brown, silty sand & SM & A-2-4 (0), A-5 \\
\hline $\mathbf{4 . 5}$ & 86 & 10.3 & 3.7 & Pale brown, silty sand & SP-SM & A-1-b, A-2-7 \\
\hline
\end{tabular}

\subsection{Chemical Composition of Soils}

The chemical composition of studied soils are listed in Table 3, revealing that soils in Najran comprise about 0.230 percent to 0.266 percent soluble mineral salt, 0.08 to 0.089 sulfur trioxide, and 0.062 to 0.086 sodium chloride. The PH of the soils of Najran ranges from 7.3 to 7.7, suggesting that they could be counted alkaline. If greater than $1 \%$ of the dissolved salts are soluble, some form of intervention is required, like blend the base soil with sufficient extracted soil, soak and compact the soil if the dissolved salt concentration is higher than $6 \%$. It can be noted that the proportion from both $\mathrm{SO}_{3}$ and $\mathrm{NaCl}$ in Najran soils is lower. 
Table 3

Chemical analysis of Najran soils.

\begin{tabular}{|lllll|}
\hline $\begin{array}{l}\text { Depth } \\
(\mathrm{m})\end{array}$ & $\mathrm{pH}$ & $\begin{array}{l}\text { Soluble mineral salt } \\
(\%)\end{array}$ & $\mathrm{SO}_{3}$ & $\mathrm{NaCl}$ \\
\hline 1.5 & 7.7 & 0.230 & 0.080 & 0.062 \\
\hline $\mathbf{3}$ & 7.3 & 0.263 & 0.089 & 0.077 \\
\hline 4.5 & 7.3 & 0.266 & 0.084 & 0.086 \\
\hline
\end{tabular}

\subsection{Attreberg Limits Test Results}

The Atterberg limits test results of the soils are presented in Table 4. It is noted that the plasticity index PI $=1.3$ is in the range between 1 and 5 , suggesting a moderate plasticity of the soil. The liquidity index for Najran soil is negative (less than zero) which means drier and stiff soil. This also confirmed by the high values of consistency index $(\mathrm{Cl})$ and SPT-N values. Thus when sheared, the soil might be treated as a brittle fracture. Najran soil quality index is higher than one, indicating the soil is semi-solid and rigid. For the determination of the liquid limit, a cone penetrometer system (according to BS: 1377 and IS: 2720) was utilized with a normal mold size with a diameter and a depth of $55 \mathrm{~mm}$ and $40 \mathrm{~mm}$, respectively. It allows the LL to be calculated easily and rapidly. There are many advantages to the cone penetrometer process compared to the Casagrande technique. It is not so reliant on the tools configuration and is applicable to an inclusive variety of soils. By determining the moisture content of rolling thread specimens that form an even diameter of about $3 \mathrm{~mm}$, the plastic limit of the soil samples was obtained.

Table 4

Consistency results of Najran soil specimens

\begin{tabular}{|llllll|}
\hline $\begin{array}{l}\text { Depth } \\
(\mathbf{m})\end{array}$ & $\begin{array}{l}\text { LL } \\
(\%)\end{array}$ & $\begin{array}{l}\text { PL } \\
(\%)\end{array}$ & $\begin{array}{l}\text { PI } \\
(\%)\end{array}$ & $\begin{array}{l}\text { Liquidity } \\
\text { Index (LI) } \\
(\%)\end{array}$ & $\begin{array}{l}\text { Consistency } \\
\text { Index (CI) } \\
(\%)\end{array}$ \\
\hline $\mathbf{1 . 5}$ & 15.3 & 11.0 & 4.3 & -2.04 & 3.04 \\
\hline $\mathbf{3}$ & 16.7 & 12.8 & 3.9 & -2.38 & 3.38 \\
\hline $\mathbf{4 . 5}$ & 17.9 & 13.7 & 4.2 & -2.07 & 3.07 \\
\hline
\end{tabular}

The improvement in Atterberg limits in various soil samples treated with Cement Kiln Dust (CKD) was researched by Miller and Azad (2000). The results showed that increasing in CKD content led to increasing in the $\mathrm{Pl}$, a decrease in the liquid threshold and thus a huge reduction in the $\mathrm{PI}$ happens with CKD definitive stabilization for soils having higher values of PI. 
Conclusions of Attreberg experiments showed that the salt addition influences the soil consistency. As seen in the figure below, an increase in salt addition reduces the $L L, P L$, and contributes to a reduction in the PI.

Table 5

\begin{tabular}{|c|c|c|c|c|}
\hline \multirow{2}{*}{$\begin{array}{l}\text { Samples } \\
\text { depth (m) }\end{array}$} & \multirow{2}{*}{$\begin{array}{l}\mathrm{NaCl} \\
(\%)\end{array}$} & \multicolumn{3}{|c|}{ Atterberg Limits } \\
\hline & & LL (\%) & PL (\%) & $\mathrm{PI}(\%)$ \\
\hline \multirow[t]{4}{*}{1.5} & 0 & 22.85 & 17.72 & 5.13 \\
\hline & 5 & 16.23 & 14.14 & 2.09 \\
\hline & 10 & 13.04 & 12.32 & 0.72 \\
\hline & 20 & 12.19 & 11.76 & 0.43 \\
\hline \multirow[t]{4}{*}{3} & 0 & 20.7 & 14.04 & 6.66 \\
\hline & 5 & 16.37 & 12.41 & 3.96 \\
\hline & 10 & 16.51 & 12.65 & 3.86 \\
\hline & 20 & 16.20 & 10.95 & 5.25 \\
\hline \multirow[t]{4}{*}{4.5} & 0 & 21.98 & 17.80 & 4.18 \\
\hline & 5 & 20.56 & 16.71 & 3.85 \\
\hline & 10 & 17.26 & 14.08 & 3.18 \\
\hline & 20 & 17.04 & 14.81 & 2.23 \\
\hline
\end{tabular}

\subsection{Compaction Characteristics}

It is worth noticing through the standard proctor compaction tests that changes occurred in results when salt was introduced to the soil. Adding more of salt led to a decrease in the optimum water content and an increase in the maximum dry density, as shown in Table 6 and Figs. 4 (a, b, c, d), 5, 6 and 7. This new features of salt stabilized soils enhance their strength and ability for bearing high loads and therefore they can be utilized in roads structure construction as subbase layers. The salinity of soil water causes fine particles stack with large particles in a process known as flocculation. This phenomenon interprets the reasons of increasing dry density of slats stabilized soils. 
Table 6

Compaction test results for natural and treated soil samples

\begin{tabular}{|c|c|c|c|}
\hline Samples Depth (m) & $\mathrm{NaCl}(\%)$ & O.M.C (\%) & Maximum Dry Density $\left(\mathrm{g} / \mathrm{cm}^{3}\right)$ \\
\hline \multirow[t]{4}{*}{1.5} & 0 & 9.47 & 1.995 \\
\hline & 5 & 7.946 & 2.001 \\
\hline & 10 & 7.823 & 2.015 \\
\hline & 20 & 7.01 & 2.02 \\
\hline \multirow[t]{4}{*}{3} & 0 & 13.7 & 1.93 \\
\hline & 5 & 10.15 & 1.96 \\
\hline & 10 & 9.95 & 1.959 \\
\hline & 20 & 9.58 & 1.99 \\
\hline \multirow[t]{4}{*}{4.5} & 0 & 11.29 & 1.96 \\
\hline & 5 & 9.4 & 1.972 \\
\hline & 10 & 9.08 & 1.98 \\
\hline & 20 & 8.09 & 2.03 \\
\hline
\end{tabular}

\subsection{CBR Test Results}

For materials to be used in pavement structures (i.e subbase layer or subgrade), it is necessary to know their performance in advanced. Thus, serval CBR tests for soils specimens collected from different depths $(1.5,3$ and $4.5 \mathrm{~m})$ treated with $20 \%$ of $\mathrm{Nacl}$ as well as the untreated specimens (i.e natural soil) were conducted. Tests were performed on soils stabilized with $20 \%$ Nacl since they demonstrated higher maximum dry density in compaction test. Specimens were prepared with variation densities by applying different compaction energy and then they were subjected to soaked CBR test. The relationships between dry density and CBR are plotted in Fig. 8. It is clear from the figure that, there is a significant effect of addition $20 \% \mathrm{Nacl}$ to the soil in different depths in which the CBR percentages increased significantly compared to the CBR percentages of untreated soil specimens. The ratio of CBR increasing sometimes reached to more than $50 \%$. The benefit of these curves is to predict the CBR value corresponding to a specific dry density of stabilized soil according to the purpose of using in road layers with either light, medium or high traffic loading.

\subsection{Shear Strength Test Results}

The results of direct shear box tests on the natural soils samples and soils samples stabilized with $20 \%$ of $\mathrm{Nacl}$ are presented in Fig. 9 and Fig. 10, respectively. For the purpose of comparison, the results of shear strength parameters in both figures are summarized in Table 7. The results presented indicated that 
the addition of $20 \% \mathrm{Nacl}$ to the soils at different depths increased the shear strength parameters ( $\mathrm{C}$ and $\phi)$ which means increased the shear strength of the treated soils. These results are in consistence with the trend obtained in compaction and CBR tests results. The increase in shear strength parameters of stabilized soils is attributed to the increase in the friction forces between soil particles due to the salts adhesion on the soil particles surfaces forming rough surfaces.

Table 7

Shear strength parameters for natural soils and treated soils with $20 \% \mathrm{Nacl}$ at different depths.

\begin{tabular}{|llll|}
\hline Soil Type & Depth $(\mathrm{m})$ & Cohesion $\left(\mathrm{Kg} / \mathrm{cm}^{2}\right)$ & Angel of internatl friction (degree) \\
\hline Natural soil & 1.5 & 0.1333 & 24 \\
\cline { 2 - 4 } & 3 & 0.0872 & 25.5 \\
\cline { 2 - 4 } & 4.5 & 0.0533 & 29 \\
\hline Soil + 20\% Nacl & 1.5 & 0.1843 & 27.8 \\
\cline { 2 - 4 } & 3 & 0.1034 & 30 \\
\hline & 4.5 & 0.0372 & 33 \\
\hline
\end{tabular}

\section{Mechanism Of Stabilization}

Since soil samples taken at depth 4.5 showed higher dry density when compacted with the addition of various percentage of $\mathrm{NaCl}$ (i.e 5, 10 and 20\%), scanning electron microscope (SEM) were performed for some representative compacted samples to figure out the mechanism of stabilization.

Figure 11 demonstrates the SEM analysis of stabilized specimens of soil with $5 \%, 10 \%$ and $20 \%$ of $\mathrm{NaCl}$. Samples were taken from specimen compacted at the optimum water content corresponding to high maximum dry density and images are displayed in $400 \times$. After the adding of $5 \%$ of $\mathrm{NaCl}$ to the normal soil specimens (Fig. 11a), salt penetrated into voids between the soils grains and a decrease in soil porosity was demonstrated, however, voids between soil particles are still clearly shown. Moreover, the addition of $10 \% \mathrm{NaCl}$ (Fig.11b) shows a gradual increase in particles densification and flocculation compared to soil structure with $5 \% \mathrm{NaCl}$ (Fig. 11a). Lastly, the addition of $20 \% \mathrm{NaCl}$ (Fig. 11c) resulted in a flocculated and high dense structure (high dry density), which means high strength and this is clear from the compaction results trend. Furthermore, crystallized salts act as a skeleton and were adsorbed on the soil grains surface and increase its roughness as can be seen clearly in Figure 11. 
Figure 12 displays SEM of soil treated with $20 \% \mathrm{NaCl}$ and EDX at spectrum1. The EDX shown in Figure $12 \mathrm{~b}$ shows the existence of $\mathrm{O}, \mathrm{Na}, \mathrm{Mg}, \mathrm{Si}, \mathrm{Cl}$ and $\mathrm{Ca}$ with about 14.64, 35.17, 2.44, 3.03, 44.04 and $0.67 \%$ by weight, respectively. The high percentage of sodium $(\mathrm{Na})$ and chloride $(\mathrm{Cl})$ is due to the adding of $20 \%$ of $\mathrm{NaCl}$ to normal soil specimens and it is clearly seen from Figure 12a the salts crystals adsorbed on the surface of soil particles.

\section{Conclusions}

- The goal of this research was to investigate the influence of sodium chloride $(\mathrm{NaCl})$ on the index and engineering properties such as liquid limit, plastic limit, plasticity index, compaction, CBR and shear strength characteristics of various samples of Najran soil taken from different depths (1.5, 3, and 4.5 $\mathrm{m})$. The inorganic sodium chloride $(\mathrm{NaCl})$ added percentages were $0,5,10$, and 20 percent. On the basis of the test results in this report, the following conclusions can be drawn:

- As the percentage of salt applied to semi-arid soils increased, the overall dry density increased and the optimal water content decreased.

- The LL and PL and in turn PI of soils decreased as the added percentage of sodium chloride increased.

- The addition of $\mathrm{NaCl}$ significantly increases the CBR indicating that salt stabilized soils could be used in subbase layer or subgrade for medium to high traffic volume roads.

- Crystallized salts act as a skeleton, are adsorbed on the soil grains surface, increasing its roughness and in turn increase the strength of the soil structure.

- Sodium chloride could be a good stabilizing agent for semi-arid soils in of Najran soil especially for highway construction.

\section{Declarations}

Conflict of Interest: The authors declare that they have no conflict of interest.

Funding: This study was not supported by any external fund.

\section{References}

Abd El-Aal AK, Salah MK, Khalifa MA (2020) Acoustic and strength characterization of Upper Cretaceous dolostones from the Bahariya Oasis, Western Desert, Egypt: The impact of porosity and diagenesis. J. Petrol. Sci. Eng., 187, 106798. https://doi.org/10.1016/j.petrol.2019.106798

Abd El Aal, A.K., Rouaiguia, A. (2020): Determination of the Geotechnical Parameters of Soils Behavior for Safe Future Urban Development, Najran Area, Saudi Arabia: Implications for Settlements Mitigation. Geotech Geol Eng 38, 695-712 (2020). https://doi.org/10.1007/s10706-019-01058-x 
Abdullah G. M. S. and Al-Abdul Wahhab H. I. (2015) "Evaluation of foamed sulfur asphalt stabilized soils for road applications," Construction and Building Materials, vol. 88, pp. 149-158.

Abdullah G. M. S. and Al-Abdul Wahhab H. I. (2018). Stabilisation of soils with emulsified sulphur asphalt for road applications, Road Materials and Pavement Design, DOI: 10.1080/14680629.2018.1436465.

Abood, T. T., Kasa, A. B., and Chik, Z. B. (2007). Stabilisation of Silty Clay Soil using Chloride Compounds. Journal of Engineering Science and Technology, Vol. 2(1), pp. 102-110 .

Afrin H. (2017). Stabilization of Clayey Soils Using Chloride Components. American Journal of Civil Engineering 2017; 5(6): 365-370.

Al-Amoudi, Omar, Al-Homidy, Abdullah, Maslehuddin, M and A. Saleh, Tawfik. (2017). Method and Mechanisms of Soil Stabilization Using Electric Arc Furnace Dust. Scientific Reports. 7. 46676. 10.1038/srep46676.

Al-Homidy A A, Dahim M H and Abd El Aal A K (2017): Improvement of geotechnical properties of sabkha soil utilizing cement kiln dust Journal of Rock Mechanics and Geotechnical Engineering Volume 9, Pages $749-60$

Al-Malak, M. H., Abdullah, G. M., Al-Amoudi O.S.B., and Bukhari A. A. (2016). Stabilization of indigenous Saudi Arabian soils using fuel oil flyash. Journal of King Saud University .Engineering Sciences Volume 28, Issue 2, Pages 165-173.

Dubey P. and Jain R. (2015). Effect of Common Salt (Nacl) on Engineering Properties of Black Cotton Soil. International Journal of Science Technology \& Engineering | Volume 2 | Issue 01.

Durotoye, T.O, Akinmusuru, J.O, Ogbiye, A.S, and Bamigboye, G.O. (2016). Effect of Common Salt on the Engineering Properties of Expansive Soil. International Journal of Engineering and Technology Volume 6 No.7.

El-Shafie M (2010) Sustainability versus mega urban development projects. Int J of Civ and Environ Eng IJCEE-IJENS 10(04):1-7.

Guttikonda R. and Abhilash N. (2018). Stabilization of Black Cotton Soil Using Sodium Chloride. International Journal of Advance Research, Ideas and Innovations in Technology, Volume 4, Issue 1.

Homidy A.A, Dahim M. H., Abd El Aal, A.K. (2017). Improvement of geotechnical properties of sabkha soil utilizing cement kiln dust. Journal of Rock Mechanics and Geotechnical Engineering Volume 9, Issue 4, Pages 749-760.

Lopez-lara T. and Castano V.M. (2001). Time dependency of Cao Treated Expansive Soils. Electronic Journal of Geotechnical Engineering Vol.7. 
Miller, G.A., Azad, S., (2000). Influence of soil type on stabilization with cement kiln dust. Construction and Building Materials Vol. 14, Issue 2 pp: 89-97.

Muntohar, A.S. and Hantoro, G. (2000) Influence of Rice Husk Ash and Lime on Engineering Properties of a Clayey Subgrade. Electronic Journal of Geotechnical Engineering, 5, 1-13.

Peddaiah S. and Suresh K. (2017). Experimental Study on Effect of Gypsum and NaCl in Improvement of Engineering Properties of Clayey Soil. International Journal of Engineering and Technology (IJET), Volume 9 No.4.

Rouaiguia, A., El Aal, A.K.A. (2020): Enhancement of the Geotechnical Properties of Soils Using Marble and Lime Powders, Guelma City, Algeria. Geotech Geol Eng 38, 5649-5665 (2020). https://doi.org/10.1007/s10706-020-01368-5

Singh, G. and Das, B. M. 1999, "Soil Stabilization with Sodium Chloride," Transportation Research Record, Vol. 1673, pp. 46-55.

\section{Figures}




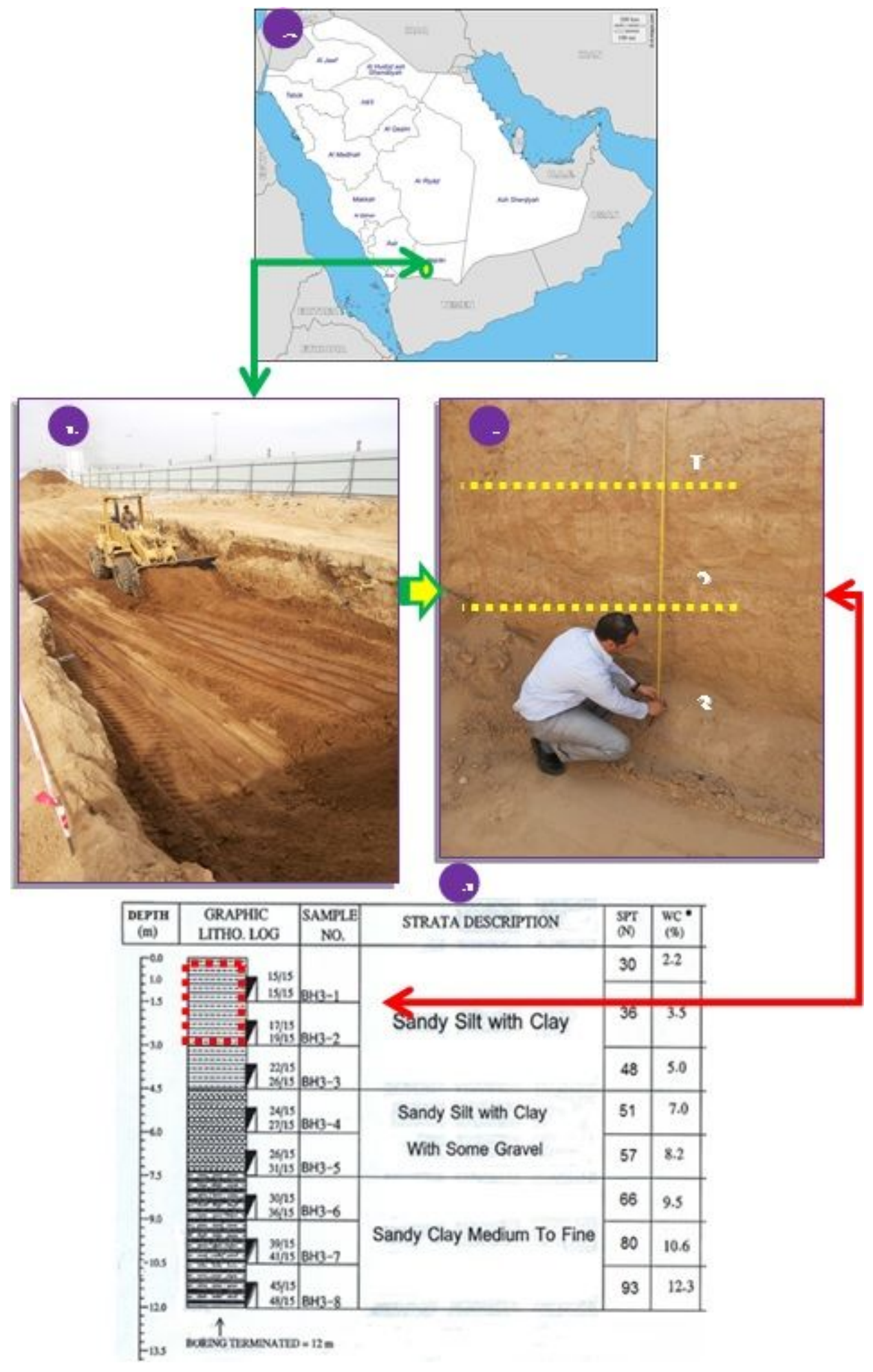

Figure 1

(a) Location map for soil sample area examined, b and c, View of drilling and sampling at different depths, d, Najran soil typical soil profile (borehole log) (see ditched area). 


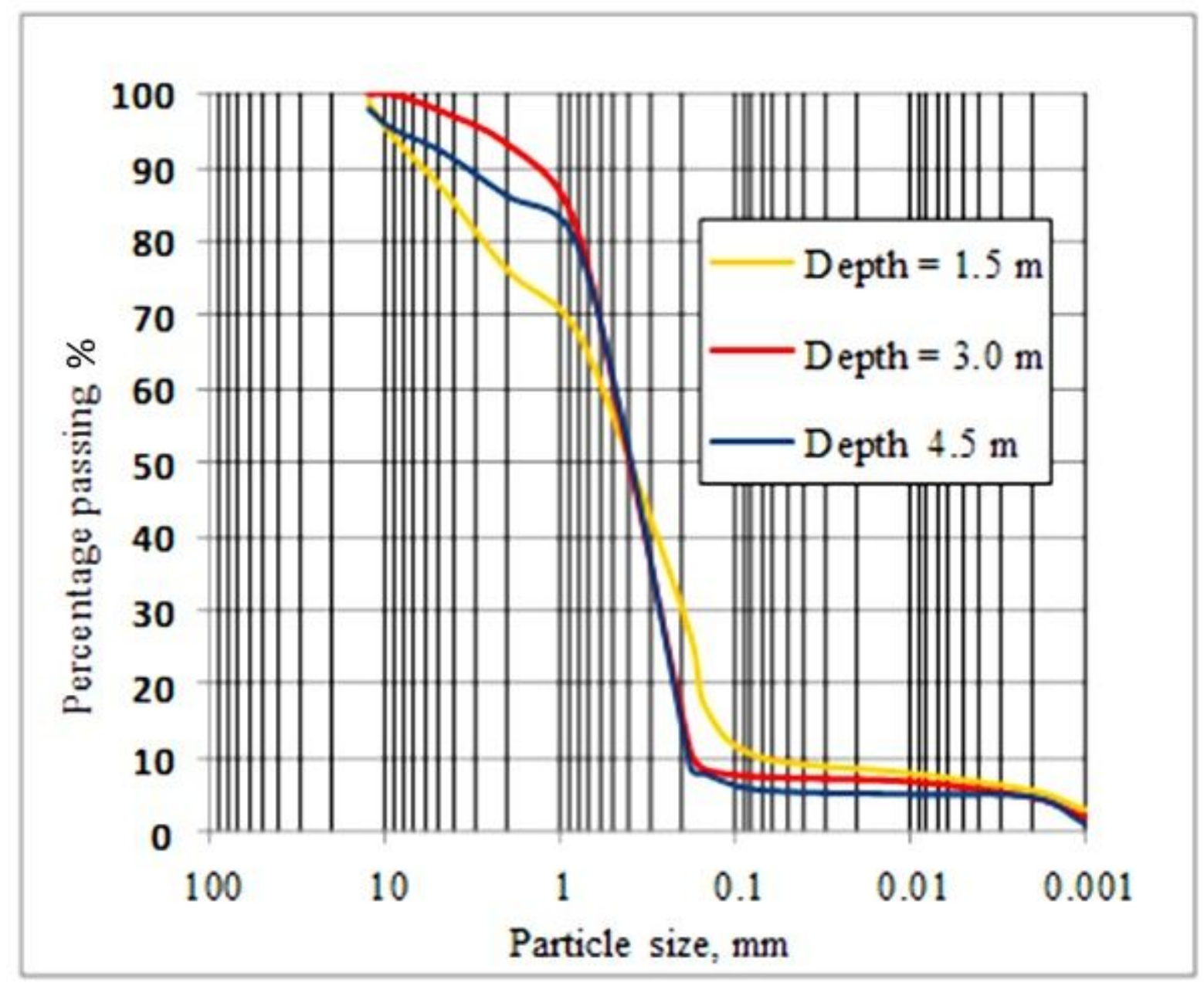

Figure 2

Grains size distribution for Najran soils. 


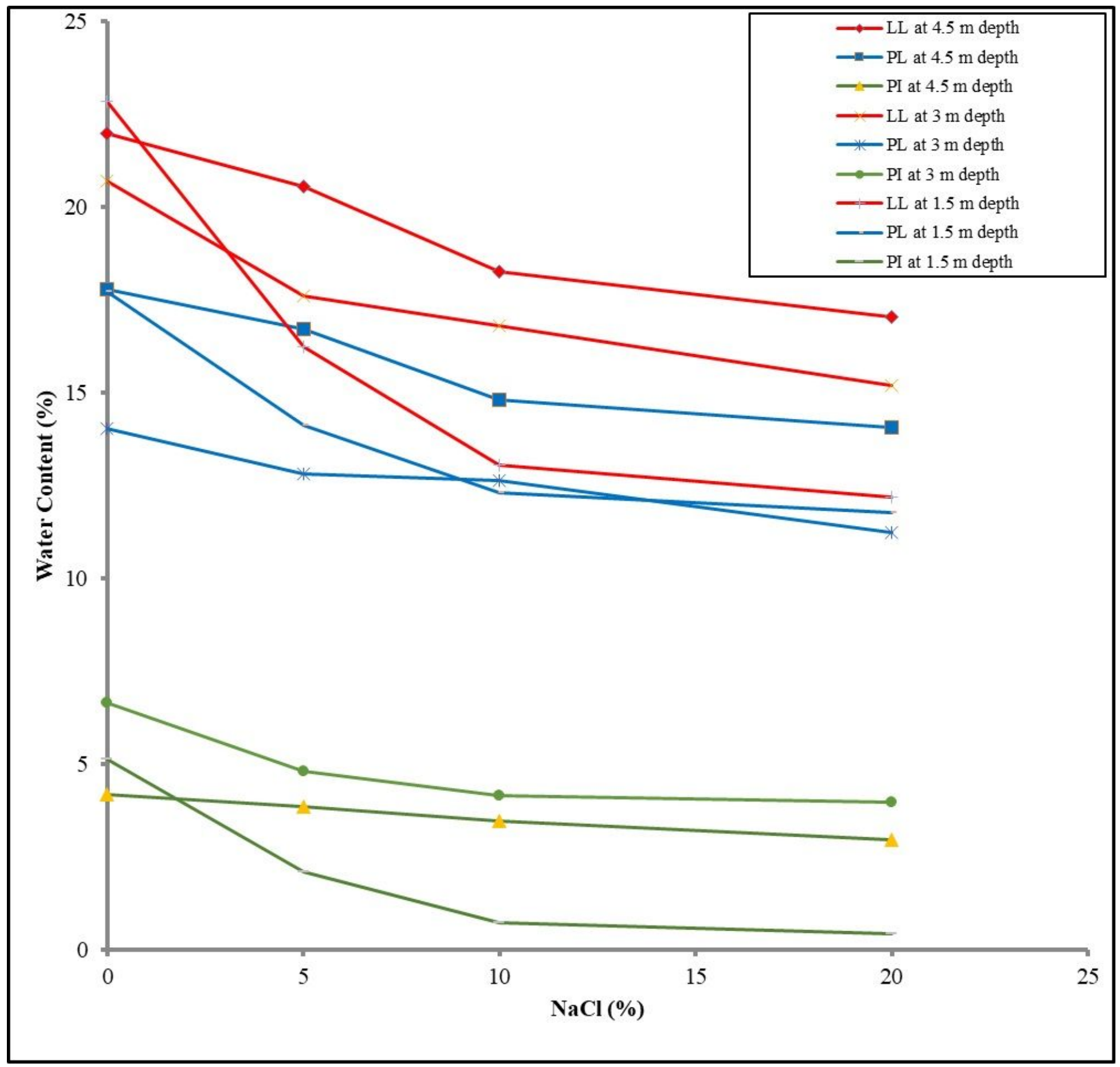

Figure 3

Effect of different $\mathrm{NaCl}$ percentages on Atterberg limits of soil at different depths. 

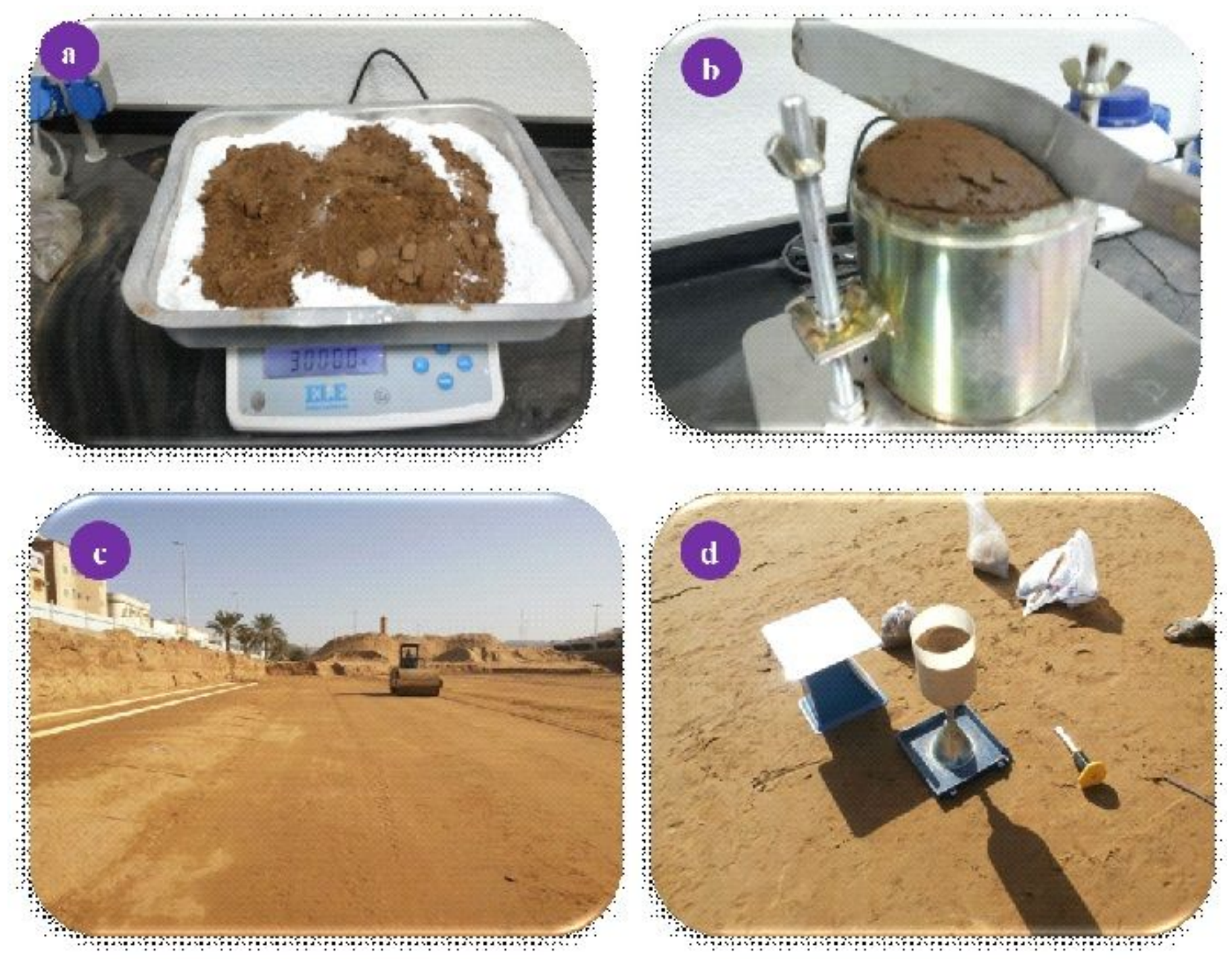

Figure 4

a, b Proctor compaction tests of Alluvial soils with chloride in the laboratory, c, d, filed compaction after mixing with sodium chloride. 


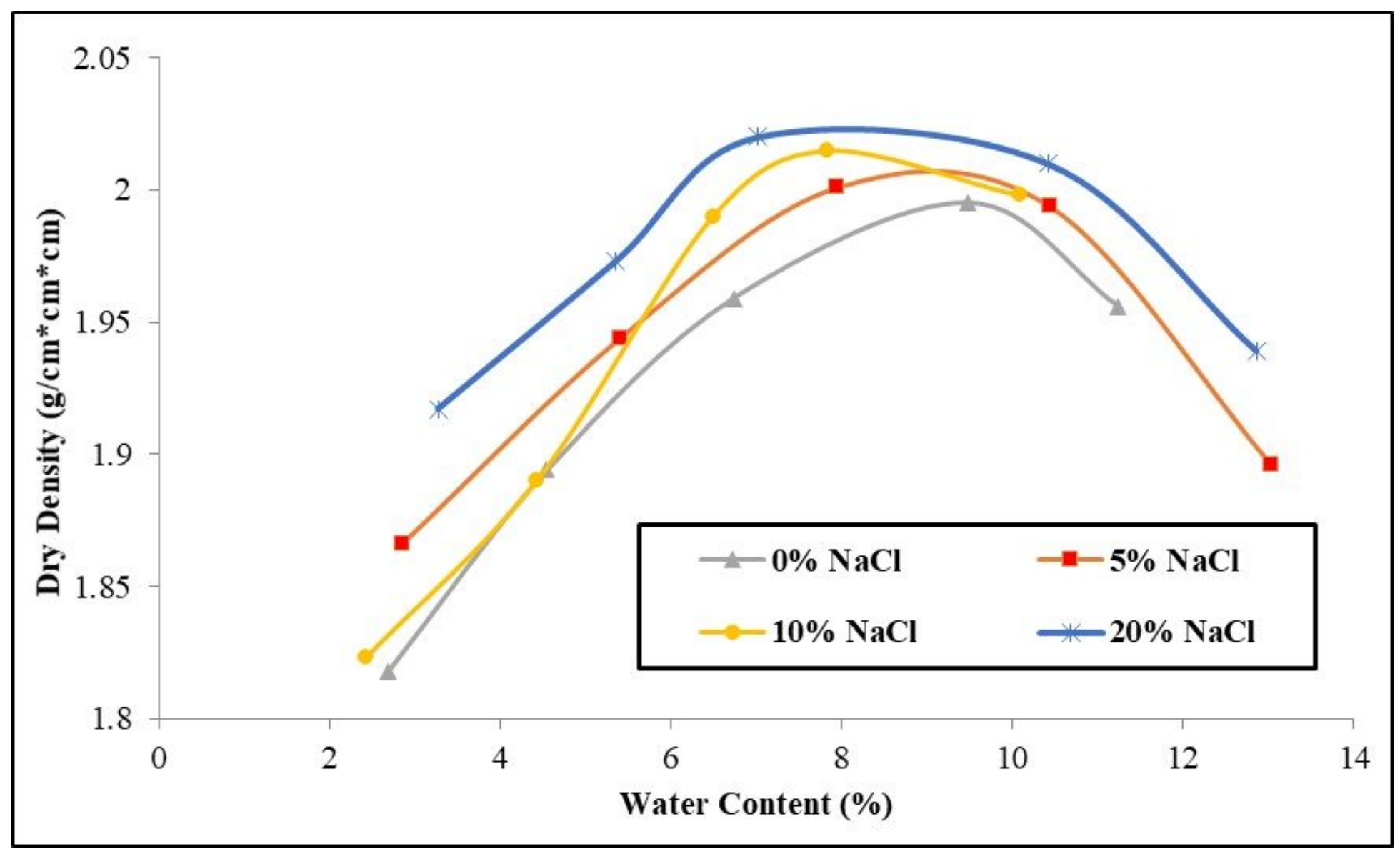

Figure 5

Dry density versus moisture content of different $\mathrm{NaCl} \%$ for soil at $1.5 \mathrm{~m}$ depth. 


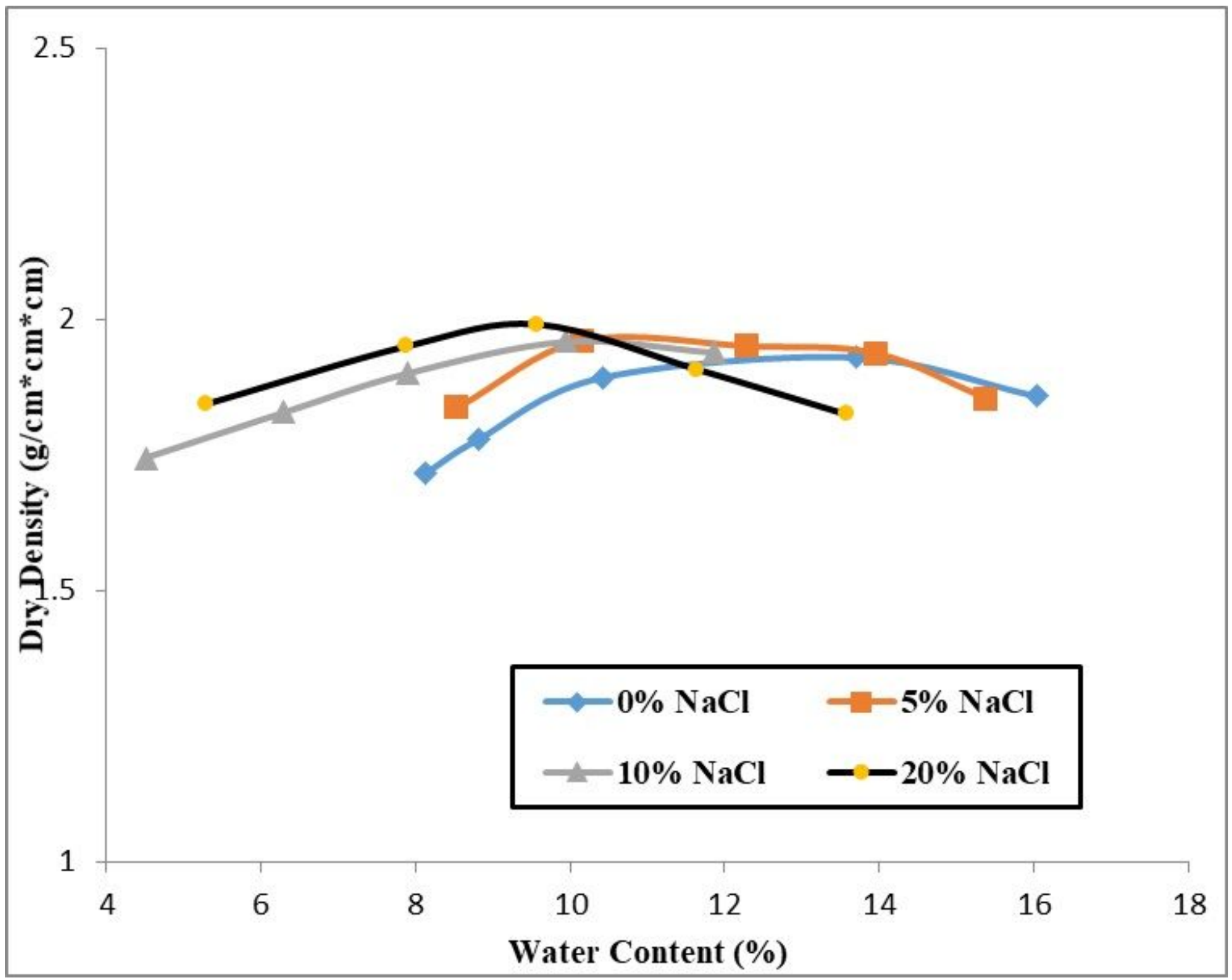

Figure 6

Dry density versus moisture content of different $\mathrm{NaCl} \%$ for soil at $3 \mathrm{~m}$ depth. 


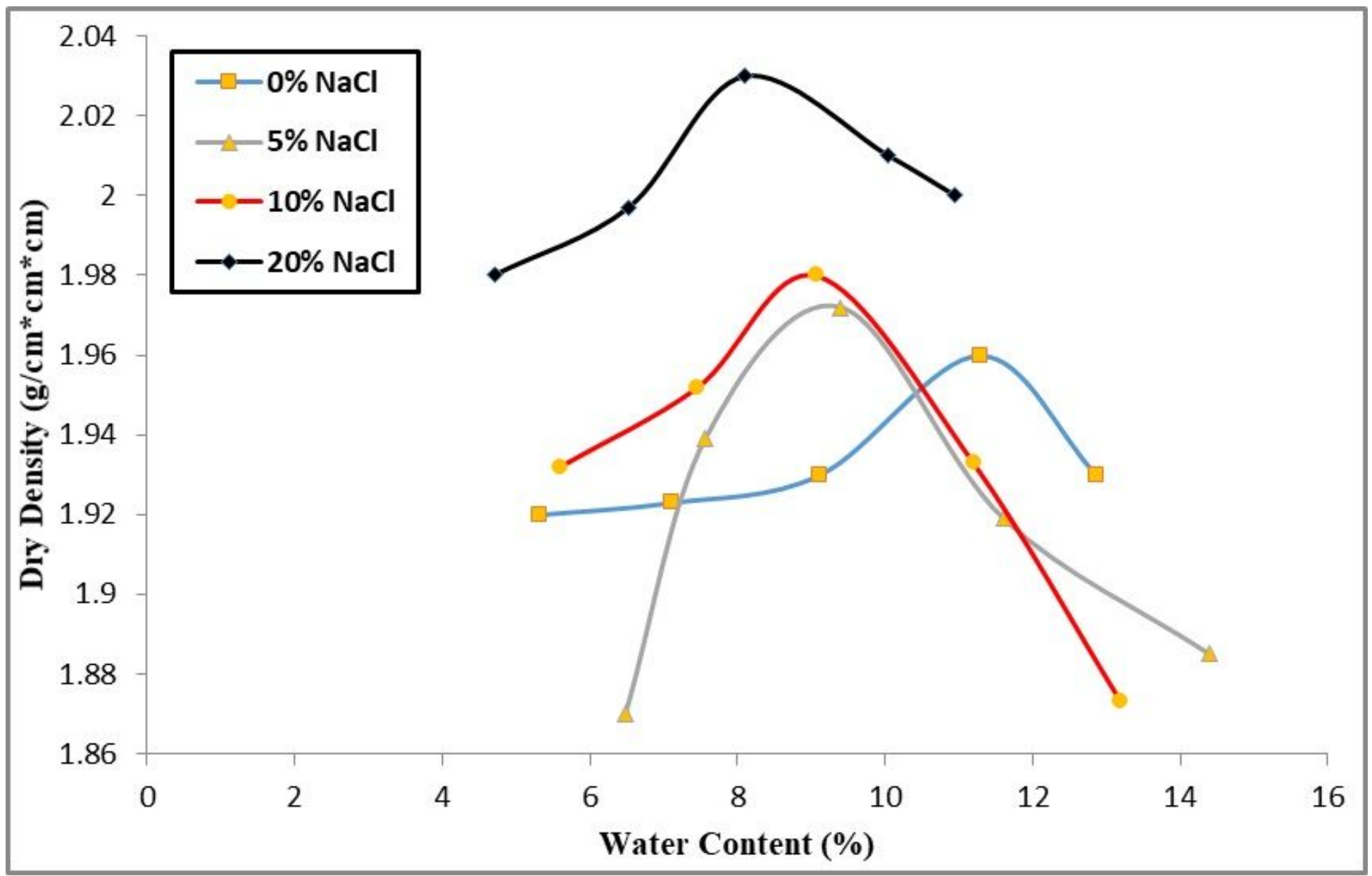

Figure 7

Dry density versus moisture content of different $\mathrm{NaCl} \%$ for soil at $4.5 \mathrm{~m}$ depth. 


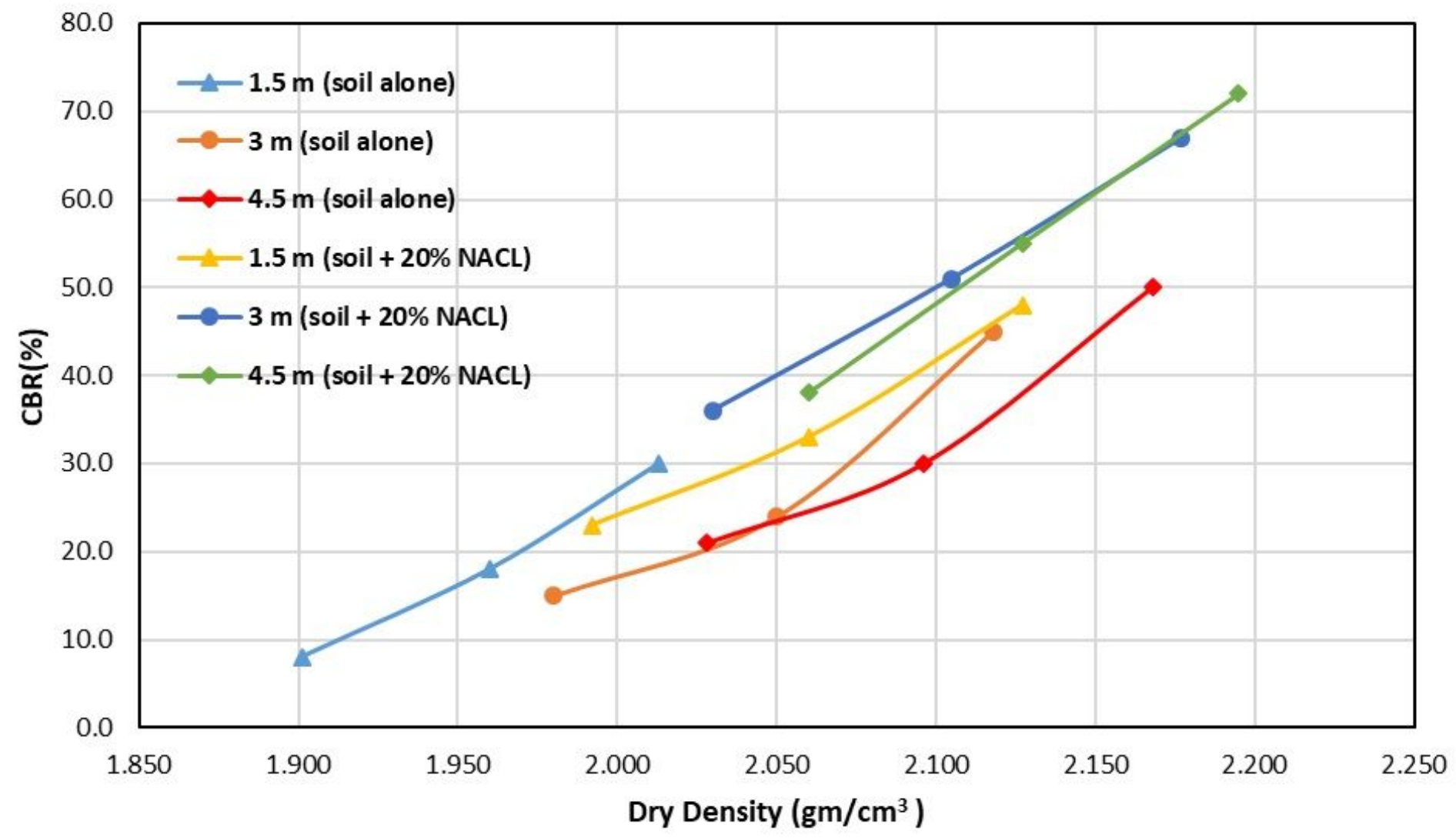

Figure 8

CBR versus dry density for untreated soil and treated with $20 \% \mathrm{Nacl}$ at different depths.

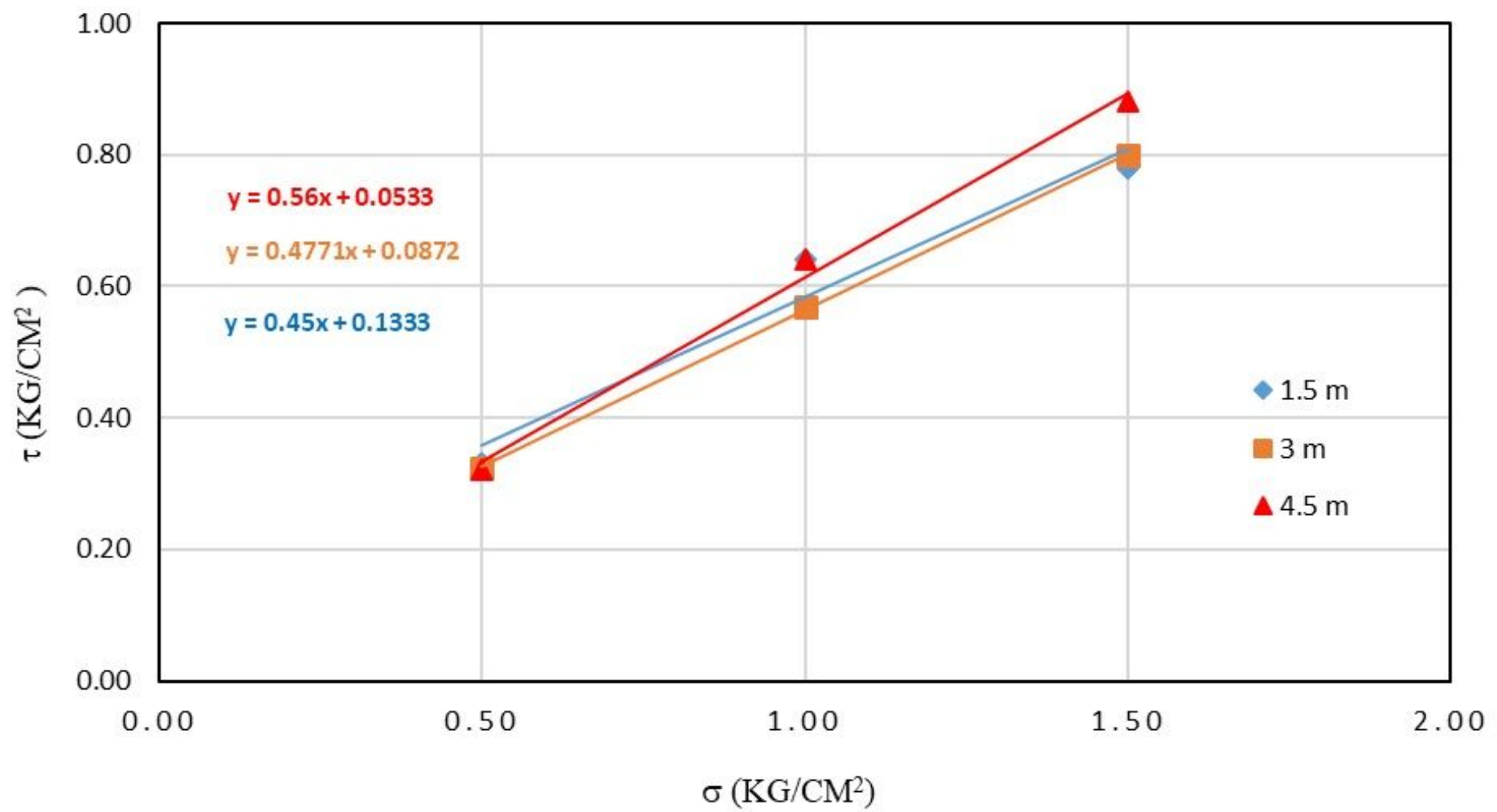


Figure 9

Shear strenth results for natural soil at different depths

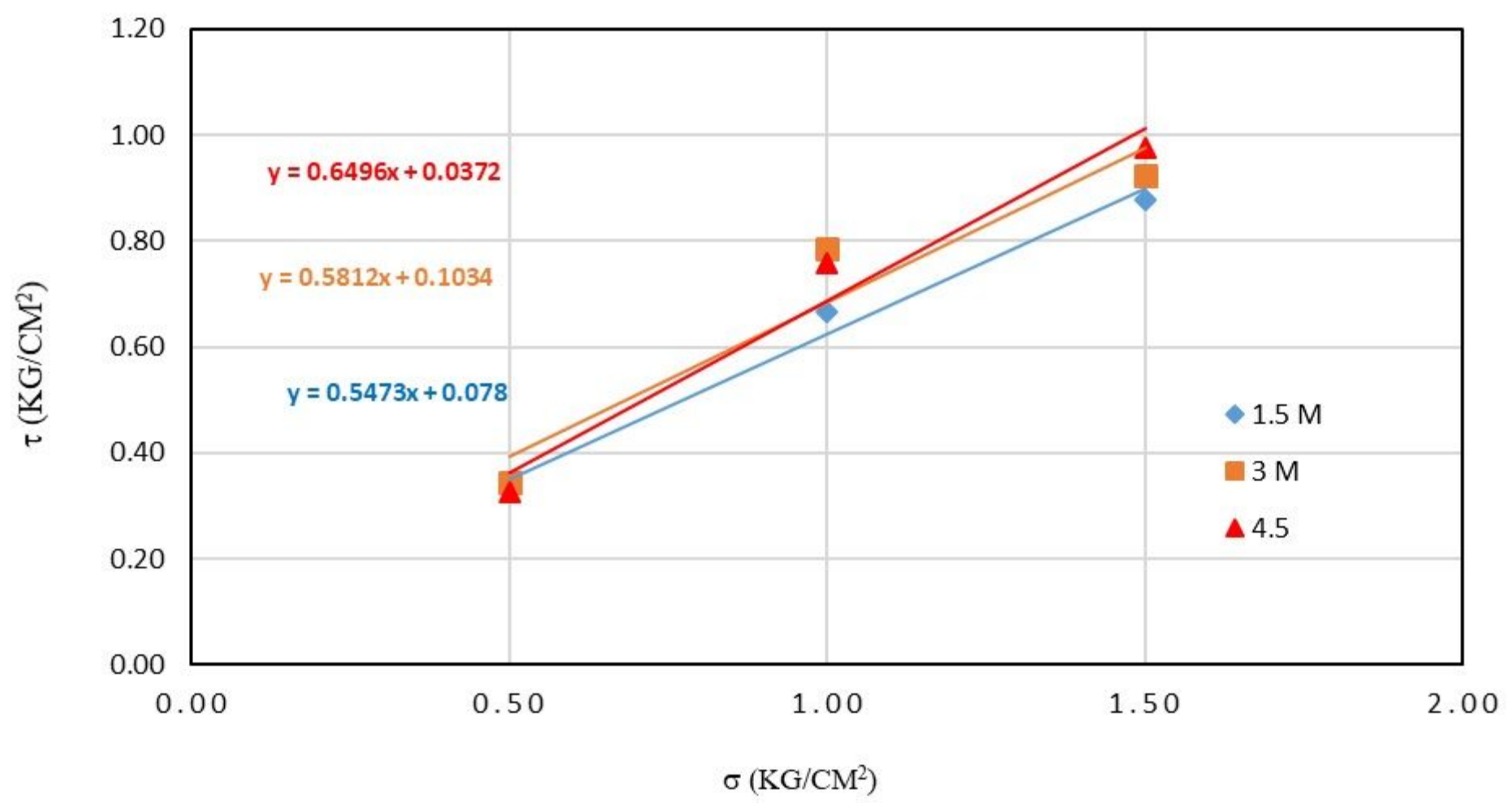

Figure 10

Shear strenth results for treated soil with $20 \%$ of Nacl at different depths. 

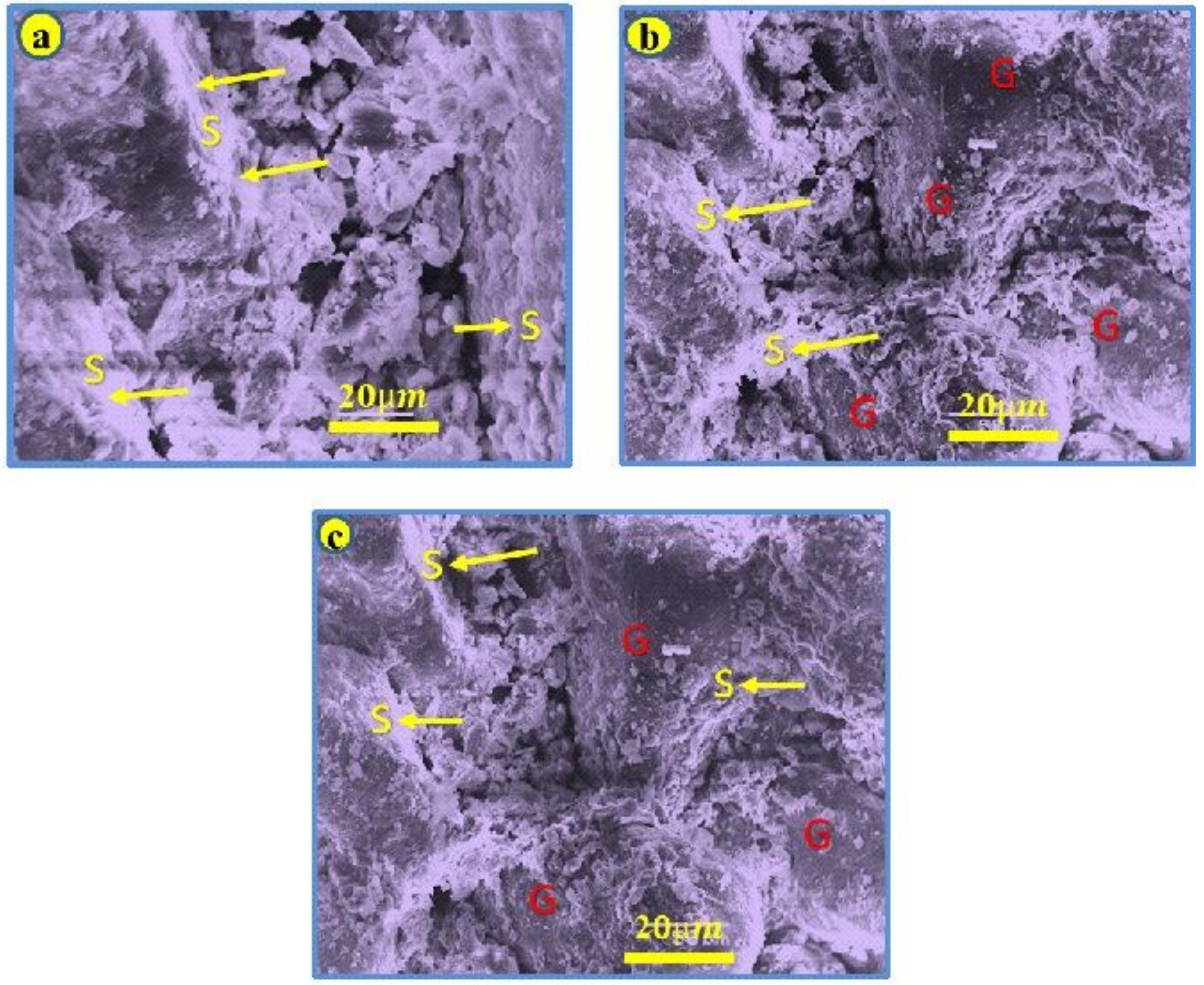

Figure 11

SEM images (400x) a) $5 \% \mathrm{NaCl}$ b) $10 \% \mathrm{NaCl}$ c) $20 \% \mathrm{NaCl}$ 


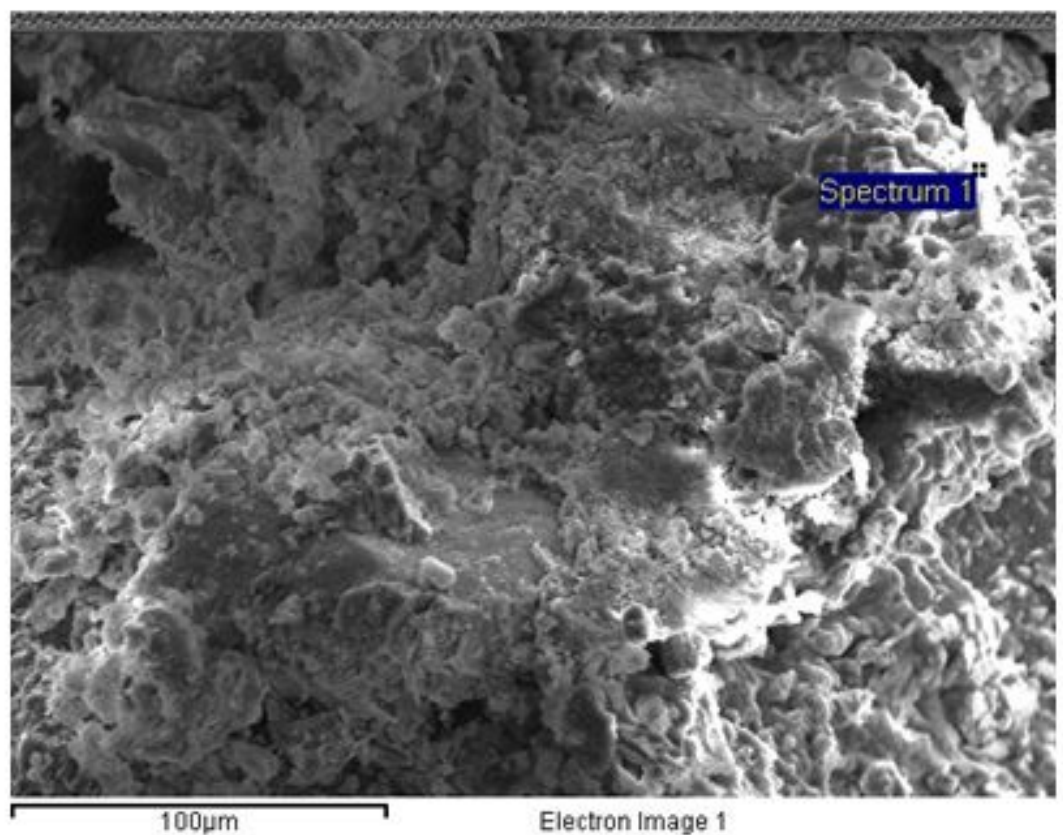

a) SEM

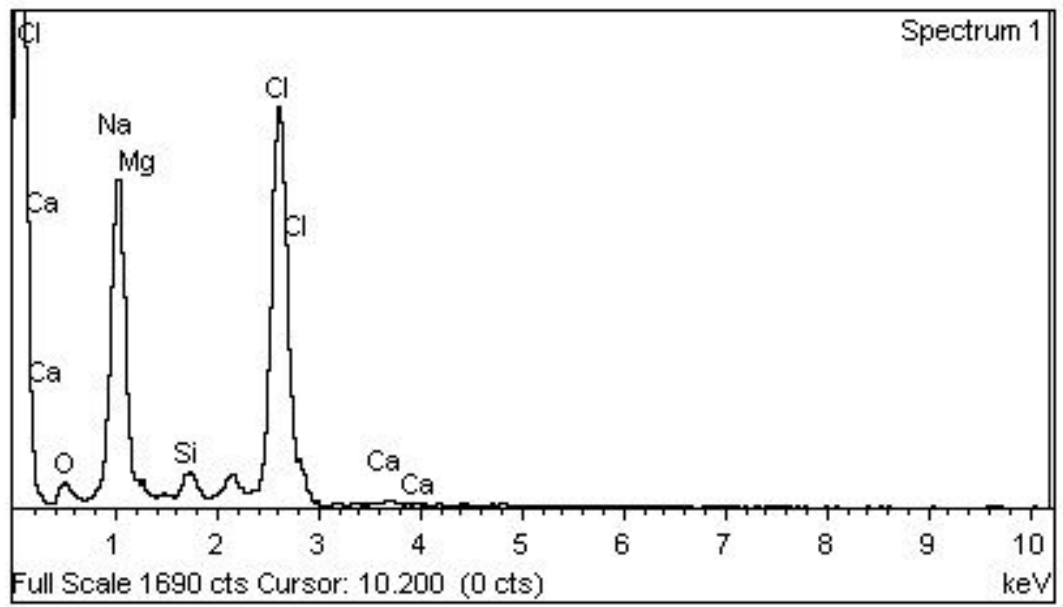

b) EDX

Figure 12

SEM and EDX of soil with $20 \% \mathrm{NaCL}$. 